\title{
Beef conjugated linoleic acid isomers reduce human cancer cell growth even when associated with other beef fatty acids
}

\author{
Anne De La Torre ${ }^{1}$, Eric Debiton ${ }^{2}$, Pierre Juanéda ${ }^{3}$, Denys Durand ${ }^{1}$, Jean-Michel Chardigny ${ }^{3}$, \\ Chantal Barthomeuf ${ }^{2}$, Dominique Bauchart ${ }^{1}$ and Dominique Gruffat ${ }^{1}$ * \\ ${ }^{1}$ INRA, Unité de Recherche sur les Herbivores, Equipe Nutriments et Métabolismes, 63122 Saint Genès-Champanelle, France \\ ${ }^{2}$ Laboratoire de Pharmacognosie/Biotechnologies; UMR 484 INSERM, 63005 Clermont-Ferrand, France \\ ${ }^{3}$ INRA, Unité de Nutrition Lipidique, 21065 Dijon, France
}

(Received 20 May 2005 - Revised 19 August 2005 - Accepted 27 September 2005)

\begin{abstract}
Although many data are available concerning anticarcinogenic effects of industrial conjugated linoleic acid (CLA), few studies have reported the antitumour properties of CLA mixtures originating from ruminant products. The aim of the present study was to investigate the in vitro antiproliferative effects of beef CLA mixtures on breast, lung, colon, melanoma and ovarian human cancer cell lines. For this purpose, four fatty acid (FA) extracts prepared from beef lipid and varying in their CLA composition, their corresponding purified CLA-enriched fractions, and mixtures of pure synthetic CLA, the composition of which reproduced that of the four selected beef samples, were tested on cancer cell lines. Cancer cells were exposed for $48 \mathrm{~h}$ to medium containing $100 \mu \mathrm{M}-\mathrm{FA}$ and their proliferation was determined by quantifying cellular DNA content (Hoechst 33342 dye). Compared with cells incubated without FA, the number of cancer cells was reduced from 25 to $67 \%(P<0.0001)$ following FA treatment. Antiproliferative effects of CLA mixtures varied in magnitude according to the source of FA, the CLA composition and the cell lines. CLA mixtures naturally present in beef inhibited the proliferation of human cancer cell lines, a high content in cis-trans isomers allowing the most important antiproliferative effect. Beef total FA exhibited a greater growth-inhibitory activity than their corresponding CLA-enriched fractions. These results suggested that either beef FA other than beef CLA could possess antiproliferative properties and/or the existence of complementary effects of nonconjugated FA and CLA, which could favour the antiproliferative properties of beef total FA.
\end{abstract}

Beef: Fatty acids: Conjugated linoleic acid: Human cancer cells: Growth inhibition

Conjugated linoleic acid (CLA) is a collective name for a group of positional and geometric isomers of linoleic acid (cis-9,cis-12-18:2) in which the double bonds are separated by a single $\mathrm{C}-\mathrm{C}$ bond. It is a substance naturally provided by fat from ruminant products (milk and meat) which constitute the major source of dietary CLA for human consumers (Pariza et al. 2001) as at least twenty-four distinct CLA isomers (Cruz-Hernandez et al. 2004), the cis-9,trans-11-CLA isomer (rumenic acid) representing more than $80 \%$ of total CLA (Griinari \& Bauman, 1999). In addition, synthetic CLA mixtures can be generated industrially by catalytic hydrogenation of vegetable oils (Kritchevsky, 2000). The cis-9,trans11- and trans-10,cis-12-CLA isomers predominate in these preparations $(85-90 \%)$, these two isomers usually being represented in equal amounts with the presence of other minor CLA isomers (10-15\%) (Gnädig et al. 2001).

Over the past two decades, extensive research indicates that CLA mixtures could possess numerous beneficial properties for human health including anticarcinogenic, antiadipogenic, antiatherogenic and antidiabetogenic properties (Belury, 2002). Their anticarcinogenic properties have been widely studied using synthetic CLA, i.e. cis-9,trans-11- and trans-10,
cis-12-CLA isomers tested either individually or in a 50/50 mixture. In vivo studies of experimental carcinogenesis using rodents as the animal model for man have shown that synthetic CLA prevent tumour development in mammary, colon, forestomach and skin tumours (Belury \& Vanden Hauvel, 1997). In the same way, in vitro studies have demonstrated that synthetic CLA inhibit, in a dose- and timedependent manner, the proliferation of several human tumour cell lines from breast, lung, prostate, skin and colon (Kelly, 2001; Belury, 2002). Although many in vivo and in vitro experiments have investigated biological properties of synthetic CLA isomers, few have reported antitumour effects of complex CLA mixtures naturally present in lipids of ruminant meat and milk. O'Shea et al. (2000) have showed that CLA-enriched milk fat is as effective as a synthetic CLA mixture in decreasing breast tumour cell (MCF-7) proliferation. These antiproliferative effects are independent of the composition of FA other than CLA in milk fat samples, suggesting that CLA isomers could be the active compounds (O'Shea et al. 2000). Properties of natural CLA mixtures could differ from those of synthetic CLA because of specific properties of each CLA isomer. The trans-10,cis-12-isomer, 
virtually absent in ruminant products, is actually the most potent isomer in inhibiting the proliferation of colon cancer cells (Kim et al. 2002; Miller et al. 2002). The cis-9,trans11-isomer exhibited greater antiproliferative effects than its cis-9,cis-11-conterpart in both colorectal and prostate cancer cells (Palombo et al. 2002). These different effects of the various isomers could be explained, at least in part, by different mechanisms and/or targets of action of isomers (Pariza et al. 2000). For example, the trans-10,cis-12-isomer may act on prostate cancer cells through the modulation of apoptosis and of cell control whilst the cis-9,trans-11-isomer might alter preferentially arachidonic acid metabolism (Ochoa et al. 2004).

In this context, the aim of the present study was to investigate the antiproliferative properties of CLA mixtures that occur naturally in beef. For this purpose, four samples of beef FA differing in their CLA composition (different proportions in cis,trans-, cis,cis- and trans,trans-isomers) were selected. Antiproliferative properties of (1) total FA present in the selected beef; (2) CLA-enriched fractions purified from the four FA examples, and (3) a synthetic CLA mixture composed of 9,11-CLA isomers reproducing the composition of CLA present in selected beef were compared in breast, lung, melanoma, colon, and ovarian human cancer cell lines by the measurement of changes in cellular DNA content using Hoechst 33342 dye.

\section{Materials and methods}

\section{Fatty acid extraction and analysis}

Eight crossbred Charolais $\times$ Salers steers (412 (SD 33) d old; live weight 536 (SD 33) $\mathrm{kg}$ ) were selected on the basis of live weight and daily gain. Animals were assigned at random to two groups (four for each diet) for a $70 \mathrm{~d}$ feeding study. Animals were given the basal diet (45\% natural hay and $55 \%$ concentrate) alone or with extruded linseed providing lipids at the level of $4 \%$ dietary DM. All steers were slaughtered conventionally at the abattoir of the Research Centre (INRA-Theix) and the carcasses chilled at $4{ }^{\circ} \mathrm{C}$ for $24 \mathrm{~h}$ before sampling. Muscle samples were taken for chemical analysis from Longissimus thoracis, Rectus abdominis, Semitendinosus and Pectoralis transversus. Total lipids were extracted from muscle samples $(150 \mathrm{~g})$ according to the method of Folch et al. (1957). Extraction and transmethylation of FA into methyl esters (FAME) was realised by using sodium methanolate solution $(0 \cdot 5 \mathrm{M})$ according to the method of Christie (2001). FAME composition was determined by GLC (DI 200 chromatograph; Perichrom, Saulx les Chartreux, France) using a glass capillary column $(100 \mathrm{~m}$ length $\times 0.25 \mathrm{~mm}$ internal diameter) coated with CP-Sil 88 (oven temperature programme $70-215^{\circ} \mathrm{C}$ ). $\mathrm{H}_{2}$ was used as the carrier gas (at a flow rate of $1 \cdot 1 \mathrm{ml} / \mathrm{min}$ ). Chromatographic signals were analysed by Winilab II Chromatography Data System software (Perichrom, Paris, France). The FA composition was calculated using an internal standard method (C19:0). A reference standard (mix C4-C24 methyl esters; Supelco, Bellefonte, PA, USA) and CLA standard mix (Sigma-Aldrich, Isle d'Abeau Chesnes, France) were used to determine recoveries and correction factors for the determination of individual FA composition of beef fat.

\section{Total fatty acids of selected beef samples}

Among thirty-two beef samples analysed, four samples were selected for their specific CLA composition (Longissimus thoracis and Pectoralis transversus of steers given the control and linseed-supplemented diets) and their FA composition is presented in Table 1. Briefly, all beef samples were dominated by the cis,trans-CLA isomer (namely, the cis-9,trans-11isomer) but additionally, sample A was characterised by a high content of cis,cis- and trans,trans-CLA isomers (mix A), sample B possessed a high content of cis, cis- and a low content of trans,trans-isomers (mix B), sample $\mathrm{C}$ had an equivalent medium content of cis,cis- and trans,trans-CLA isomers (mix C) and finally, sample D showed a low cis,cisand trans,trans-isomer content. In order to determine the ability of these FA mixtures to inhibit human tumour cell proliferation, approximately $20 \mathrm{mg}$ total lipids of each sample were extracted and their FA were saponified by a $10 \% \mathrm{KOH}$ ethanolic solution overnight at room temperature (Bauchart \& Aurousseau, 1981). Free FA were solubilised in absolute ethanol at a concentration of $100 \mathrm{~mm}$ and kept at $-20^{\circ} \mathrm{C}$ until use (in the 2 weeks following their preparation).

\section{Preparation of beef conjugated-linoleic-acid-enriched fatty acid fractions}

Beef CLA-enriched fractions were prepared as FAME from total FA of the four selected samples. Beef FAME were successively fractionated by preparative and semi-preparative HPLC followed by silver nitrate TLC $\left(\mathrm{AgNO}_{3}-\mathrm{TLC}\right)$. Briefly, the preparative HPLC (a Water Prep LC System 500 coupled with axial modul preparative column; Waters, Guyancourt, France) was carried out on a reverse phase column $(20 \mathrm{~cm}$

Table 1. Fatty acid (FA) composition of the four beef samples (mixes $A-D)$ selected for their specific composition of isomers of conjugated linoleic acid (CLA)

\begin{tabular}{|c|c|c|c|c|}
\hline & $\operatorname{Mix} A^{*}$ & Mix B十 & Mix C‡ & Mix D§ \\
\hline \multicolumn{5}{|l|}{ FA composition ( $\%$ total FA) } \\
\hline$\Sigma$ Saturated FA & $50 \cdot 27$ & 39.84 & 49.96 & 39.75 \\
\hline Of which $16: 0$ & $25 \cdot 20$ & $21 \cdot 34$ & $25 \cdot 55$ & 21.29 \\
\hline Of which 18:0 & $20 \cdot 36$ & 14.56 & $19 \cdot 81$ & 14.47 \\
\hline$\Sigma$ MUFA & 39.96 & $45 \cdot 74$ & 35.90 & 43.08 \\
\hline Of which trans-11-18: 1 & 2.65 & $2 \cdot 72$ & 1.95 & $2 \cdot 86$ \\
\hline Of which cis-9-18: 2 & $29 \cdot 31$ & 35.40 & 28.09 & 33.84 \\
\hline$\Sigma$ PUFA & 4.40 & 6.46 & 6.43 & 8.04 \\
\hline Of which $18: 2 n-6$ & $3 \cdot 76$ & 4.44 & $5 \cdot 18$ & 6.65 \\
\hline Of which $18: 3 n-3$ & 0.89 & 1.08 & 0.77 & 0.80 \\
\hline Total CLA & 0.540 & 0.932 & 0.479 & 0.593 \\
\hline Of which $\Sigma$ cis, trans & 0.446 & 0.526 & 0.437 & 0.567 \\
\hline Of which $\Sigma$ cis, cis & 0.052 & 0.066 & 0.020 & 0.019 \\
\hline Of which $\Sigma$ trans, trans & 0.042 & 0.039 & 0.023 & 0.008 \\
\hline$\Sigma$ Unknown FA & 5.43 & $7 \cdot 03$ & $7 \cdot 23$ & 8.54 \\
\hline \multicolumn{5}{|c|}{ CLA composition (\% total CLA) } \\
\hline$\sum$ cis,trans & $82 \cdot 6$ & $88 \cdot 7$ & $91 \cdot 0$ & 95.5 \\
\hline$\Sigma$ cis, cis & $9 \cdot 6$ & $7 \cdot 1$ & $4 \cdot 2$ & $3 \cdot 2$ \\
\hline$\sum$ trans, trans & $7 \cdot 8$ & $4 \cdot 2$ & $4 \cdot 8$ & 1.3 \\
\hline
\end{tabular}

${ }^{*} \mathrm{FA}$ of Longissimus thoracis muscle of Charolais $\times$ Salers steers fed a linseedsupplemented diet.

†FA of Pectoralis transversus muscle of Charolais $\times$ Salers steers fed a linseedsupplemented diet.

¥FA of Longissimus thoracis muscle of Charolais $\times$ Salers steers fed a control diet. $\S \mathrm{FA}$ of Pectoralis transversus muscle of Charolais $\times$ Salers steers fed a control diet. 
length, $7 \mathrm{~cm}$ internal diameter) using a Lichroprep RP 18 (Merck KGat, 6427 Darmstadt, Germany) as previously described by Sébédio et al. (1987). FAME (up to $6 \mathrm{~g}$ ) were dissolved in acetone and chromatography was performed with pure methanol as the solvent system (flow rate $150 \mathrm{ml} / \mathrm{min}$ ). The fraction containing C18:2 FAME including CLA was collected, dried under $\mathrm{N}_{2}$ and dissolved in hexane (up to $40 \mathrm{mg}$ ) to be fractionated on a reverse phase column (Nucleosil C18 Interchim, Montluçon, France, $5 \mu \mathrm{m}$, $25 \mathrm{~cm} \times 10 \mathrm{~mm}$ internal diameter;) by semi-preparative HPLC (Spectra-Physics SP8810 pump coupled with RID 10A detector; Newport Corporation, Mountain View, CA, USA) using pure acetonitrile as the solvent system (flow rate $4 \mathrm{ml} / \mathrm{min}$ ). The FAME fraction containing CLA was thereafter refined by $\mathrm{AgNO}_{3}$-TLC (reference 5721, 0.25 mm thickness; Merck KGat, 6427 Darmstadt, Germany) using pure toluene as the eluant according to the method of Morris (1966). FAME were viewed under UV after spraying $2^{\prime} 7^{\prime}$ dichlorofluorescein $(0.1 \%$ in ethanol). The band containing CLA was recovered and FA composition was analysed by GLC as described earlier. FA composition of these four CLA semi-purified fractions from beef is given in Table 2. Mixes E, F, G and $\mathrm{H}$ were the CLA-enriched FAME fractions purified from total FA of mixes A, B, C and D, respectively (Table 1). FAME mixes were converted into free FA counterparts, solubilised in absolute ethanol at the concentration of $175 \mathrm{~mm}$ and kept at $-20^{\circ} \mathrm{C}$ until use (in the 2 weeks following their preparation).

\section{Preparation of synthetic conjugated linoleic acid mixtures}

Synthetic CLA mixtures containing cis-9,trans-11-CLA, cis-9,cis-11-CLA and trans-9,trans-11-CLA (Matreya Inc., Pleasant Gap, PA, USA) were prepared to mimic the CLA composition of selected beef samples (Table 3 ). Concentrations

Table 2. Fatty acid (FA) composition of conjugated linoleic acid (CLA)enriched mixes (mixes $\mathrm{E}-\mathrm{H}$ ) prepared from beef samples selected for their specific composition of isomers of CLA

\begin{tabular}{|c|c|c|c|c|}
\hline & Mix $E^{*}$ & Mix F† & Mix G‡ & Mix $\mathrm{H} \S$ \\
\hline \multicolumn{5}{|l|}{ FA composition (\% total FA) } \\
\hline Non-conjugated FA & $42 \cdot 6$ & $29 \cdot 2$ & $34 \cdot 4$ & $37 \cdot 4$ \\
\hline $14: 0$ & $1 \cdot 3$ & $2 \cdot 0$ & $3 \cdot 2$ & $4 \cdot 4$ \\
\hline$\sum$ trans-16: 1 & $32 \cdot 3$ & $21 \cdot 8$ & $25 \cdot 3$ & $22 \cdot 3$ \\
\hline$\sum$ cis- $16: 1$ & 3.5 & $2 \cdot 3$ & $2 \cdot 3$ & $4 \cdot 1$ \\
\hline $17: 0$ & $2 \cdot 4$ & 1.6 & $2 \cdot 1$ & $1 \cdot 8$ \\
\hline$\Sigma 18: 2$ & $3 \cdot 2$ & 1.6 & 1.5 & 4.9 \\
\hline$\Sigma$ Unknown FA & $3 \cdot 2$ & $2 \cdot 1$ & $3 \cdot 0$ & $4 \cdot 3$ \\
\hline Total CLA & $54 \cdot 2$ & $68 \cdot 6$ & $62 \cdot 6$ & $58 \cdot 3$ \\
\hline Of which $\Sigma$ cis, trans & $43 \cdot 7$ & $62 \cdot 1$ & $56 \cdot 7$ & 54.9 \\
\hline Of which $\Sigma$ cis, cis & $5 \cdot 6$ & 4.5 & 2.9 & 1.9 \\
\hline Of which $\Sigma$ trans,trans & 4.9 & $2 \cdot 0$ & 3.0 & 1.5 \\
\hline \multicolumn{5}{|c|}{ CLA composition (\% total CLA) } \\
\hline$\Sigma$ cis,trans & $80 \cdot 6$ & $90 \cdot 5$ & $90 \cdot 6$ & $94 \cdot 2$ \\
\hline$\Sigma$ cis, cis & $10 \cdot 4$ & $6 \cdot 6$ & $4 \cdot 6$ & $3 \cdot 2$ \\
\hline$\Sigma$ trans, trans & $9 \cdot 0$ & $2 \cdot 9$ & $4 \cdot 8$ & $2 \cdot 6$ \\
\hline
\end{tabular}

${ }^{*} \mathrm{FA}$ of Longissimus thoracis muscle of Charolais $\times$ Salers steers fed a linseed-supplemented diet.

†FA of Pectoralis transversus muscle of Charolais $\times$ Salers steers fed a linseedsupplemented diet.

‡FA of Longissimus thoracis muscle of Charolais $\times$ Salers steers fed a control diet. $\S$ FA of Pectoralis transversus muscle of Charolais $\times$ Salers steers fed a control
Table 3. Conjugated linoleic acid (CLA) composition (\% total fatty acids) of synthetic CLA mixtures reproducing the composition of CLA present in lipids of selected beef samples (mix 1 for mix A, mix 2 for mix $\mathrm{B}$ and $\operatorname{mix} 3$ for $\operatorname{mix} \mathrm{C})^{\star}$

\begin{tabular}{lrrr}
\hline & Mix 1 & Mix 2 & Mix 3 \\
\hline cis-9, trans-11-CLA & 82.0 & 87.0 & 91.0 \\
cis-9, cis-11-CLA & 10.0 & 8.0 & 4.0 \\
trans-9, trans-11-CLA & 8.0 & 5.0 & 5.0 \\
\hline
\end{tabular}

*For details of mixes A-C, see Table 1.

of cis-9,trans-11-, cis-9,cis-11- and trans-9,trans-11-CLA isomers corresponded respectively to the concentrations of all cis,trans-, cis,cis- and trans,trans-isomers. Thus, compositions of mixes 1, 2 and 3 corresponded to the composition of mixes A, $\mathrm{B}$ and $\mathrm{C}$, respectively. A stock solution in absolute ethanol (Sigma-Aldrich, Lyon, France) was prepared for each synthetic CLA mixture $(100 \mathrm{~mm})$ and kept at $-20^{\circ} \mathrm{C}$ until use (in the 2 weeks following their preparation).

\section{Cell lines and culture conditions}

M4Beu, a human melanoma cell line, was established in the laboratory of Dr J. F. Doré (Institut National de la Santé et de la Recherche Medicale (INSERM), Unit 128, Lyon, France) from metastatic biopsy specimens and has been maintained in cell culture for almost 15 years (Jacubovich et al. 1985). Breast adenocarcinoma (MCF-7), colon adenocarcinoma (DLD-1), ovary teratocarcinoma (PA-1) and lung non-smallcell carcinoma (A-549) human cell lines were purchased from the European Collection of Cell Cultures (ECACC, Salisbury, UK). Stock cell cultures were maintained as monolayers in $75 \mathrm{~cm}^{2}$ culture flasks in a complete medium. This medium contained Glutamax Eagle's minimum essential medium with Earle's salts (reference 41090-28; Gibco-BRL, Paisley, UK) supplemented with $10 \%$ fetal calf serum naturally poor in CLA (batch 431 B; Biochrom, Montmorency, France), $1 \%$ of vitamin solution (reference 11102-037; Gibco-BRL), $1 \%$ of sodium pyruvate solution (reference 11360-039; Gibco-BRL), $1 \%$ of a mixture of non-essential amino-acids solution (reference 11140-035; Gibco-BRL) and $2 \mathrm{mg}$ gentamicin base (reference 15710-049, Gibco-BRL). All cell culture solutions were certified endotoxin-tested and sterile-filtered. Cells were grown at $37^{\circ} \mathrm{C}$ in a humidified incubator and under an atmosphere containing $5 \% \mathrm{CO}_{2}$ during a 2 -week period of adaptation before the proliferation assay. The same batch of fetal bovine serum was systematically used for all experiments to minimise the effects of inter-batch variability.

Total beef FA and synthetic CLA mixtures were tested on cell lines at a concentration of $100 \mu \mathrm{M}$. CLA-enriched fractions were tested at $175 \mu \mathrm{M}$ because of the presence of additional FA in these mixtures (Table 2), this concentration corresponding to $100 \mu \mathrm{M}$-CLA. The non-detergent effect for cellular viability of such concentrations of FA was verified in an preliminary study (data not shown).

\section{Proliferation assay}

Cells were plated at the density of $5 \times 10^{3}$ per $150 \mu 1$ culture medium in ninety-six-well microplates (Nunclon; 
Nunc, Roskild, Denmark) and allowed to adhere for $16 \mathrm{~h}$ before FA treatment. Thereafter, medium was replaced by a fresh complete culture medium supplemented with a given FA preparation (six wells by treatment) at the final FA concentration of $100 \mu \mathrm{M}$ for synthetic CLA preparations or for total beef FA and of $175 \mu \mathrm{M}$ for CLA-enriched fractions (final volume $200 \mu \mathrm{l}$ ). In these conditions, the final concentration of ethanol in culture medium was $0.25 \%$ for all experiments. In parallel, the control treatment consisted of cells incubated in ethanol $(0.25 \%, \mathrm{v} / \mathrm{v})$ without FA. Three independent experiments were performed, each six times. After $48 \mathrm{~h}$ of continuous FA exposure, the antiproliferative effect of FA was assessed by the measurement of DNA content with Hoechst dye 33342 as previously described by Debiton et al. (2003). Briefly, on the day of the assay, plates were thawed at room temperature, $100 \mu \mathrm{l}$ SDS solution $(0.01 \%, \mathrm{w} / \mathrm{v})$ in sterile distilled water were added into each well, and plates were incubated for $1 \mathrm{~h}$ at room temperature and then frozen at $-80^{\circ} \mathrm{C}$ for $1 \mathrm{~h}$. After thawing, $100 \mu \mathrm{l}$ Hoechst dye 33342 solution at $30 \mu \mathrm{g} / \mathrm{ml}$ in a hypersaline buffer (10 mM- tri(hydroxymethyl)-aminomethane-HCl, $\mathrm{pH}$ 7.4, $1 \mathrm{~mm}$-EDTA and $2 \mathrm{M}-\mathrm{NaCl}$ ) were added to each well. The plates were then incubated under soft agitation for $1 \mathrm{~h}$ protected from light at room temperature. Fluorescence was measured at $360 / 460 \mathrm{~nm}$. Under these conditions, fluorescence was proportional to the amount of cellular biomass.

\section{Statistical analysis}

Values are expressed as the means with their standard errors of three independent experiments. Global effects of cell type and of CLA preparation were tested by ANOVA using the GLM procedure in SAS (SAS Institute Inc. (1989); Cary, NC, USA). Effects tested in the model included the type of cell line (presented as cell), the nature of FA mixtures tested (presented as FA), the origin (synthetic or extracted from beef) of CLA mixtures (presented as origin), the interaction between the type of cells and the origin of FA mixtures (cell $x$ origin), the interaction between the nature of FA tested and their origin (FA $\times$ origin) and the interaction between the type of cells and the nature of FA (cell $\times$ FA). Significance was set at $P<0 \cdot 05$. From this statistical analysis, no significant interaction was observed between the nature of FA and their origin and between the nature of FA tested and the type of tumour cells (Table 4). Consequently, the effects of FA on tumour cell growth were independent of the type of cancer cell lines and vice versa. On this basis, results for each factor will be presented as follows: (i) the magnitude of response of each cancer cell lines to FA, all FA having the same origin taken together; (ii) the effects of each FA having the same origin on tumour cell growth, all cell lines taken together.

\section{Results}

Mean values for all experimental treatments were compared with that of the control treatment and are given in Table 4. These global results showed a cell-growth-inhibitory activity $(P=0.0069)$ of all FA sources and significant differences between responses of cancer cell lines $(P=0.034)$. The
Table 4. Effects of conjugated linoleic acid (CLA) mixtures composed of synthetic CLA isomers (mixes 1-3), of beef CLA-enriched mixtures (mixes $E-H$ ) and beef total fatty acids (FA) (mixes $A-D$ ) on human tumour cell line proliferation (number of cells as a percentage of control) (Mean values)

\begin{tabular}{|c|c|c|c|c|c|}
\hline Cell line... & MCF-7 & M4Beu & PA-1 & A-549 & DLD-1 \\
\hline \multicolumn{6}{|c|}{ Synthetic CLA (\% control) } \\
\hline $\operatorname{Mix} 1$ & 40 & 47 & 55 & 18 & 56 \\
\hline Mix 2 & 46 & 67 & 85 & 21 & 78 \\
\hline Mix 3 & 57 & 68 & 71 & 25 & 48 \\
\hline \multicolumn{6}{|c|}{ CLA-enriched fraction ( $\%$ control) } \\
\hline $\operatorname{Mix} E^{*}$ & 64 & 78 & 55 & 93 & 87 \\
\hline Mix F† & 59 & 76 & 57 & 92 & 86 \\
\hline Mix Gł & 63 & 70 & 47 & 84 & 79 \\
\hline Mix $H \S$ & 62 & 56 & 45 & 80 & 72 \\
\hline \multicolumn{6}{|c|}{ Total FA of bovine muscle (\% control) } \\
\hline $\operatorname{Mix} A^{*}$ & 61 & 65 & 48 & 52 & 54 \\
\hline Mix B† & 37 & 83 & 39 & 33 & 36 \\
\hline Mix C‡ & 48 & 59 & 27 & 41 & 48 \\
\hline Mix D§ & 21 & 71 & 5 & 29 & 37 \\
\hline \multicolumn{6}{|l|}{ Statistical effects } \\
\hline Residual SEM & $11 \cdot 31$ & & & & \\
\hline Cell & $P=0.034$ & & & & \\
\hline $\mathrm{FA}$ & $P=0.0069$ & & & & \\
\hline Origin & $P=0.0001$ & & & & \\
\hline Cell $\times$ origin & $P=0.0001$ & & & & \\
\hline $\mathrm{FA} \times$ origin & $P=0.6233$ & & & & \\
\hline Cell × FA & $P=0.9812$ & & & & \\
\hline
\end{tabular}

* FA of Longissimus thoracis muscle of Charolais $\times$ Salers steers fed a linseed-supplemented diet.

†FA of Pectoralis transversus muscle of Charolais $\times$ Salers steers fed a linseedsupplemented diet.

$\ddagger F A$ of Longissimus thoracis muscle of Charolais $\times$ Salers steers fed a control diet. $\S$ FA of Pectoralis transversus muscle of Charolais $\times$ Salers steers fed a contro diet.

cell-growth-inhibitory activity of CLA mixtures was different $(P=0.0001)$ according to their origin, i.e. synthetic CLA (mixes 1-3) compared with purified beef CLA (mixes A-H). Since there was no significant interaction between cell lines and FA tested, and in order to clarify the presentation of results, the magnitude of the response of each cell line to the FA source is presented with those from a common origin taken together and the effects of each FA of similar origin on cell growth presented similarly.

\section{Responses of tumour cell lines to fatty acids}

The responses of tumour cell lines to FA mixtures of synthetic 9,11-CLA isomers (Fig. 1 (A)), beef CLA-enriched mixtures (Fig. 1 (B)) and beef total FA (Fig. 1 (C)) were significantly different $(P<0 \cdot 05)$. Indeed, the tumour cells treated with any synthetic CLA mixtures (Fig. 1 (A)) achieved on 70 to $21 \%$ of the growth observed in the control. The lung cell line (A-549) was the most sensitive tumour cell line (only $21 \%$ of control numbers) among the five cell lines tested $(P<0.05)$. As illustrated in Fig. $1(\mathrm{~B})$, there is a 13 to $49 \%$ reduction in cell growth in treated cells by any CLAenriched fraction purified from beef ( 87 to $51 \%$ of control numbers), the most resistant tumour cell line being the lung cell line (A-549; $>87 \%$ of control numbers; $P<0.05)$ whereas the ovarian tumour cell line (PA-1) was the most sensitive $(51 \%$ of control numbers; $P<0.05)$. The sensitivity 

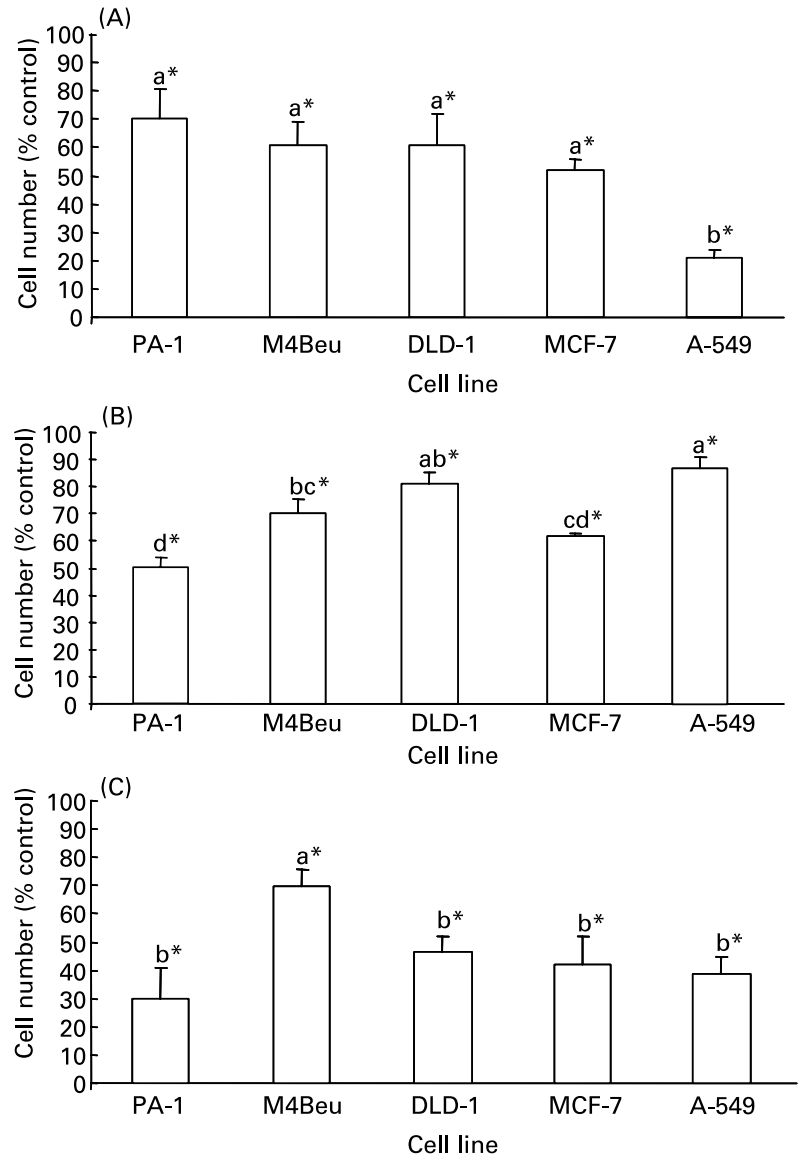

Fig. 1. Growth-inhibitory activities on each human tumour cell line to synthetic 9,11-conjugated linoleic acid (CLA) mixes (A), to CLA-enriched mixtures from beef $(B)$ and to total fatty acids $(F A)$ from beef $(C)$. Cells were cultured in complete medium supplemented with either $100 \mu \mathrm{M}$-synthetic CLA isomer mixtures, $175 \mu \mathrm{M}$-CLA-enriched mixtures or $100 \mu \mathrm{M}$-total FA extracted from selected beef samples. Control wells were treated with an equivalent volume of ethanol as treated cells $(0.25 \%, v / v)$ but without FA. Sensitivity of tumour cells against any CLA mixtures (synthetic or natural) was determined by the measurement of cellular DNA content by Hoechst 33342 dye. Values are means of three independent experiments, with their standard errors represented by vertical bars. *Mean value was significantly different from that of control $(P<0.05) .{ }^{a, b, c, d}$ Mean values with unlike letters were significantly different $(P<0.05)$.

of each tumour cell lines exposed to any total FA resulting from beef ranged from 70 to $30 \%$ of control numbers (Fig. 1 (C)). In these conditions, the melanoma cell line (M4Beu) was the most resistant to FA treatment whereas the colon (DLD-1), breast (MCF-7), lung (A-549) and ovarian (PA-1) cell lines were more sensitive (from 30 to $46 \%$ of control cells).

\section{Reductions in human tumour cell growth effected by} fatty acid mixtures

The three synthetic CLA mixtures reduced the growth of cancer cells from 40 to $57 \%$ (60 to $43 \%$ of control numbers; $P<0.0001$; Fig. 2 (A)). However, variations in the CLA composition of these mixtures did not significantly modify their antiproliferative effect.

The four CLA-enriched mixtures (mixes E-H) purified from beef contained some non-conjugated FA but their
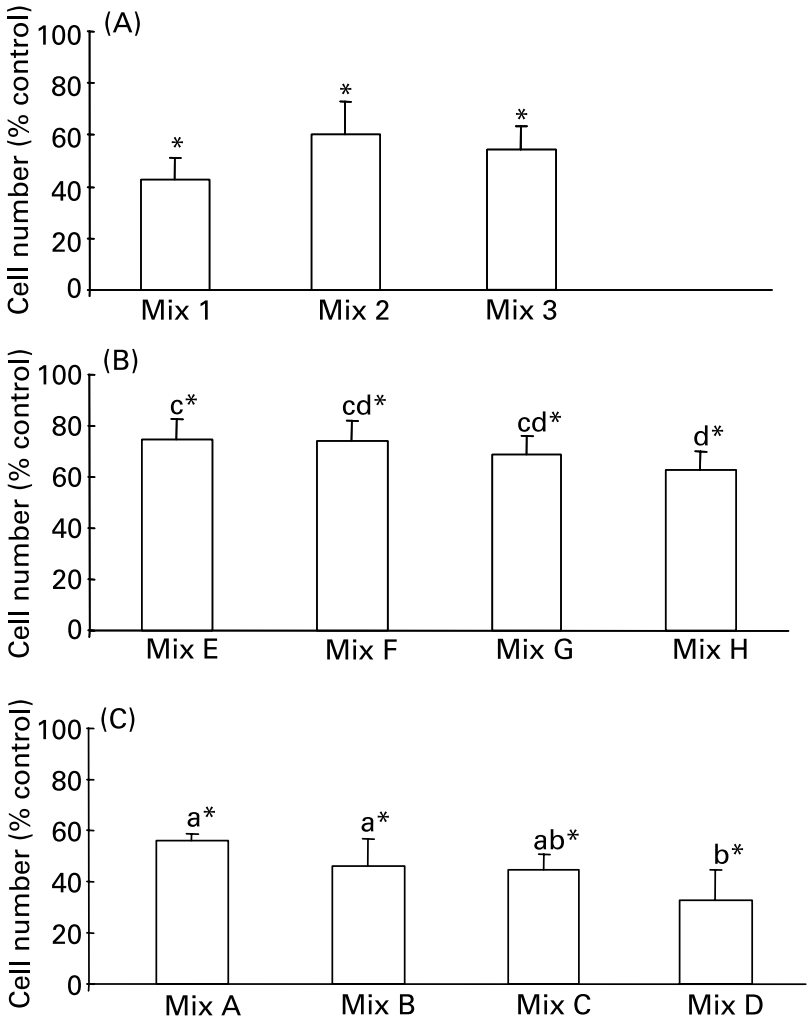

Fig. 2. Growth-inhibitory activity of synthetic 9,11-conjugated linoleic acid (CLA) mixes (A), beef CLA-enriched mixtures (B) and beef total fatty acids (FA) (C) on any human tumour cells. Cells were cultured in a complete medium supplemented with either $100 \mu \mathrm{M}$-synthetic CLA isomer mixtures, or $175 \mu \mathrm{M}$-CLA-enriched fractions or $100 \mu \mathrm{M}$-total FA extracted from selected beef samples. Control wells were treated with an equivalent volume of ethanol as treated cells $(0.25 \%, v / v)$ but without FA. Sensitivity of any tumour cells against each CLA mixture (synthetic or natural) was determined by the measurement of cellular DNA content by Hoechst 33342 dye. Values are means of three independent experiments, with their standard errors represented by vertical bars. *Mean value was significantly different from that of control $(P<0.0001)$. ${ }^{a, b, c, d}$ Mean values with unlike letters were significantly different $\left({ }^{\mathrm{a}, \mathrm{b}} P<0.05\right.$ and ${ }^{\mathrm{c}, \mathrm{d}} P<0.07$, respectively). For details of mixes, see Tables 1-3.

composition was similar between fractions (Table 2). The tumour cells treated with these CLA-enriched mixtures (Fig. 2 (B)) achieved 75 to $63 \%$ of the growth observed in the control cells $(P<0.0001)$. Among these CLA-enriched mixtures, mix $\mathrm{H}$, characterised by a high content in cis,trans-isomers and a low content in cis,cis- and trans,trans-isomers, possessed the greatest cell-growth-inhibitory activity (63\% of control cells).

Compared with control, the four total FA mixtures selected from beef (Table 1) significantly decreased human cancer cell growth (from 56 to $33 \%$ of control numbers; $P<0.0001$ ) (Fig. 2 (C)). As with the CLA-enriched mixtures, the beef FA mixture containing a high proportion of cis,trans-CLA isomers and a low content in cis,cis- and trans,trans-isomers (mix D) exerted the greatest cell-growth-inhibitory activity (33\% of control cells) and in reverse, beef FA characterised by a low content in cis,trans-isomers with a high content in cis,cis- and trans,trans-CLA isomers (mix A) possessed the lowest cell-growth-inhibitory activity (56\% of control numbers). 


\section{Discussion}

Although many data are available concerning the anticarcinogenic effects of synthetic CLA (Kelly, 2001; Kritchevsky, 2000; Belury, 2002), only few studies have reported the antitumour properties of CLA mixtures originating from ruminant products (Ip et al. 1999; O'Shea et al. 2000). In this context, the aim of the present study was to determine in several types of human tumour cells the specific antiproliferative effects of CLA-enriched FA fractions and of total FA extracted from beef differing by their CLA isomer composition.

In these experimental conditions, sensitivity of the five tumour cell lines to FA added to the medium differed as reported earlier (Shultz et al. 1992; McMillan et al. 1995; Palombo et al. 2002). Such differences in cell sensitivity could be related to the nature or to the origin of the FA supplements (synthetic CLA isomers or beef CLA). Differences in cell sensitivity to each FA could be explained by intrinsic differences in the cellular model such as the histogenic cell origin, the variable rates of cell proliferation and the specific uptake of FA by cells and their metabolic utilisation.

CLA purification from beef needed a succession of chromatographic procedures which did not allow us to obtain pure CLA mixtures. Consequently, we first investigated the antiproliferative effects of synthetic CLA mixtures using common 9,11-CLA isomers with cis,trans, cis,cis and trans,trans configurations to mimic beef CLA composition. Surprisingly, no significant differences in antiproliferative properties were noted between the three synthetic CLA mixtures, whereas several studies have shown that the effectiveness of an individual CLA isomer to inhibit cell proliferation could be different (Pariza et al. 2001; Belury, 2002). A recent study has reported that the inhibitory activity of CLA isomers on cancer-cell growth is linked to the geometrical configuration of their double bonds (Palombo et al. 2002). Indeed, the cis-9,trans11-CLA isomer exhibits a greater antiproliferative effect on both colorectal and prostate cells than does the cis-9, cis-11isomer (Palombo et al. 2002). Discrepancies between experiments (using individual isomers) and the present study (using synthetic CLA mixtures) could be explained either by differences in antiproliferative properties between CLA mixtures and their individual constituent isomers, or by a too low concentration of specific isomers such as trans,trans isomers in CLA mixtures to exhibit their antiproliferative properties. Consequently, the antiproliferative effect of these CLA mixtures could be possibly linked to the ability of the most abundant CLA isomer (cis9,trans11-isomer) to inhibit growth of the cancer cell, differences in this isomer concentration (from 82 to $91 \%$ of total CLA) being probably not sufficiently contrasted to involve differences between CLA mixtures.

The present paper reported for the first time the antiproliferative properties of four CLA-enriched fractions extracted from beef, mainly differing by the proportion of CLA isomers and not by the composition of the other FA which was relatively constant. The mixture that possessed the greater amount of non-conjugated FA was the less potent inhibitor of cancer-cell growth, indicating that these FA were not implicated in the antiproliferative effects of this mixture. These results suggested, as proposed by O'Shea et al. (2000) who have studied anticancer properties of milk fat, that CLA could be the active ingredient responsible for the antiproliferative effect of mixtures on human cancer cells. In our experimental conditions, the most active CLA-enriched mixture was characterised by the highest proportion of cis,trans-isomers and the lowest proportion of cis,cis- and trans,trans-isomers. Although cis,trans-isomers present in ruminant products are dominated by the cis-9,trans-11-isomer (Griinari \& Bauman, 1999), other minor isomers could also possess significant antitumour properties as recently reported for the cis-11,trans-13-CLA isomer which inhibits cancer-cell growth (Palombo et al. 2002).

Interestingly, total FA mixtures extracted from the beef selected strongly altered the proliferation of human cancer cells in spite of their low content of CLA $(<1 \%$ of total FA). These antiproliferative effects of total FA were higher than their corresponding CLA-enriched mixtures (55 v. $30 \%$ of inhibition of cell growth). This suggests that the ability of total FA mixtures to inhibit cancer-cell growth could be due to the presence of FA other than CLA, which could make potent the action of CLA-enriched fractions. Among these FA, stearic, palmitic and oleic acids have no specific antiproliferative properties towards colon (Caco-2) and pancreatic cancer cells (MIA PaCa-2, PANC-1 and CFPAC) (Nano et al. 2003) and may even enhance cell growth at low concentration $(5 \mu \mathrm{M})$ (Falconer et al. 1994; Awad et al. 2000). Conversely, much evidence has indicated that vaccenic and $\alpha$-linolenic acids inhibit the growth of cancer cells (Begin et al. 1988; Awad et al. 1995). Among hypotheses to explain these antitumour properties, Awad et al. (1995) have demonstrated that vaccenic acid can be taken up by cancer cells where it could be converted into the cis9,trans-11-CLA-isomer, a potent inhibitor of tumour growth (Corl et al. 2003; Miller et al. 2003). In addition, several studies have demonstrated that PUFA, especially $n-3$ FA, exhibit a great potency to inhibit growth of tumour cells (Booyens et al. 1984; Begin et al. 1988). Indeed, PUFA can undergo peroxidation, which generates free radicals and lipid peroxides leading to DNA damage and thus to inhibition of cell proliferation (Kumar \& Das, 1995; Das, 1999). However, interaction between FA, and in particular synergic effects, cannot be excluded.

The present study is the first to demonstrate that CLA mixtures naturally present in beef inhibit proliferation of human cancer cell lines. Moreover, at similar concentrations, inhibition was dependent upon the specific composition of CLA isomers present; a high content of cis,trans-isomers associated with a low content of cis,cis- and trans,trans-isomers was the most potent. In addition, total FA mixtures from beef exhibited a greater inhibitory activity on cell growth than their corresponding CLA-enriched mixtures, suggesting that FA other than CLA present in bovine tissues possess antiproliferative properties against cancer cells and, on the other hand, that relationships between FA and CLA could influence properties of such natural mixtures.

\section{References}

Awad AB, Begdache LA \& Fink CS (2000) Effect of sterols and fatty acids on growth and triglyceride accumulation in 3T3-L1 cells. J Nutr Biochem 11, 153-158. 
Awad AB, Herrmann T, Fink CS \& Horvath PJ (1995) 18:1 n7 fatty acids inhibit growth and decrease inositol phosphate release in HT29 cells compared to $n-9$ fatty acids. Cancer Lett 91, 55-61.

Bauchart D \& Aurousseau B (1981) Post-prandial lipids in blood plasma of prerumiant calves. J Dairy Sci 64, 2033-2042.

Begin ME, Ells G \& Horrobin DF (1988) Polyunsaturated fatty acidinduced cytotoxicity against tumor cells and its relationship to lipid peroxidation. J Natl Cancer Inst 80, 188-194.

Belury MA (2002) Dietary conjugated linoleic acid in health: physiological effects and mechanisms of action. Annu Rev Nutr 22, 505-531.

Belury MA \& Vanden Hauvel JP (1997) Protection against cancer and heart disease by CLA: potential mechanisms of action. Nutr Dis Update 1, 58-63.

Booyens J, Engelbrecht P, Le Roux S, Louwrens CC, van der Merwe CF \& Katzeff IE (1984) Some effects of the essential fatty acids linoleic acid and alpha-linolenic acid and of their metabolites gamma-linolenic acid, arachidonic acid, eicosapentaenoic acid, docosahexaenoic acid, and of prostaglandins A1 and E1 on the proliferation of human osteogenic sarcoma cells in culture. Prost Leuk Med 15, 15-33.

Christie WW (2001) A practical guide to the analysis of conjugated linoleic acid. Inform 12, 147-152.

Corl BA, Barbano DM, Bauman DE \& Ip C (2003) Cis-9, trans-11 CLA derived endogenously from trans-11 18:1 reduces cancer risk in rats. $J$ Nutr 133, 2893-2900.

Cruz-Hernandez C, Deng Z, Zhou J, Hill AR, Yurawecz MP, Delmonte P, Mossoba MM, Dugan ME \& Kramer JK (2004) Methods for analysis of conjugated linoleic acids and trans-18:1 isomers in dairy fats by using a combination of gas chromatography, silverion thin-layer chromatography/gas chromatography, and silverion liquid chromatography. J AOAC Int 87, 545-562.

Das UN (1999) Essential fatty acids, lipid peroxidation and apoptosis. Prost Leuk Ess Fatty Acids 61, 157-163.

Debiton E, Madelmont JC, Legault J \& Barthomeuf C (2003) Sanguinarine-induced apoptosis is associated with an early and severe cellular glutathione depletion. Cancer Chem Pharmacol 51, 474-482.

Falconer JS, Ross JA, Fearon KC, Hawkins RA, O'Riordain MG \& Carter DC (1994) Effect of eicosapentaenoic acid and other fatty acids on the growth in vitro of human pancreatic cancer cell lines. Br J Cancer 69, 826-832.

Folch J, Lees M \& Sloane-Stanley GHS (1957) A simple method for the isolation and purification of total lipids from animal tissues. J Biol Chem 226, 497-505.

Gnädig S, Rickert R, Sebedio JL \& Steinhart H (2001) Conjugated linoleic acid (CLA): physiological effects and production. Eur $J$ Lipid Sci Technol 103, 56-61.

Griinari JM \& Bauman DE (1999) Biosynthesis of conjugated linoleic acid and its incorporation into meat and milk in ruminants. In Advances in Conjugated Linoleic Acid Research, pp. vol. 1, 180-200 [J-L Sebedio, WW Christie and R Adlof, editors]. Champaign, IL: AOCS Press.

Ip C, Banni S, Angioni E, Carta G, McGinley J, Thompson HJ, Barbano D \& Bauman D (1999) Conjugated linoleic acid-enriched butter fat alters mammary gland morphogenesis and reduces cancer risk in rats. $J$ Nutr 129, 2135-2142.
Jacubovich R, Cabrillat H, Gerlier D, Bailly M \& Dore JF (1985) Tumourigenic phenotypes of human melanoma cell lines in nude mice determined by an active antitumour mechanism. $\mathrm{Br} J$ Cancer 51, 335-345.

Kelly GS (2001) Conjugated linoleic acid: a review. Alt Med Rev 6, 367-382.

Kim EJ, Holthuizen PE, Park HS, Ha YL, Jung KC \& Park JH (2002) Trans-10,cis-12-conjugated linoleic acid inhibits Caco-2 colon cancer cell growth. Am J Physiol 283, G357-G367.

Kritchevsky D (2000) Antimutagenic and some other effects of conjugated linoleic acid. Br J Nutr 83, 459-465.

Kumar GS \& Das UN (1995) Free-radical-dependent suppression of growth of mouse myeloma cells by alpha-linolenic and eicosanoic acid in vitro. Cancer Lett 92, 27-38.

McMillan D, Heys S, Alastair W, Noble B, Purasiri P, Deehan D \& Eremin O (1995) Differential responses of human tumour cells to polyunsaturated fatty acids: stimulation of proliferation of a colon tumour cell line by docosahexaenoic acid. Intern J Onc 7, 927-933.

Miller A, McGrath E, Stanton C \& Devery R (2003) Vaccenic acid (t11-18:1) is converted to c9,t11-CLA in MCF-7 and SW480 cancer cells. Lipids 38, 623-632.

Miller A, Stanton C \& Devery R (2002) Cis-9, trans-11- and trans-10, cis-12-conjugated linoleic acid isomers induce apoptosis in cultured SW480 cells. Anticancer Res 22, 3879-3887.

Morris LJ (1966) Separation of lipids by silver ion chromatography. $J$ Lipid Res 7, 717-732.

Nano JL, Nobili C, Girard-Pipau F \& Rampal P (2003) Effects of fatty acids on the growth of Caco-2 cells. Prost Leukot Essent Fatty Acids 69, 207-215.

Ochoa JJ, Farquharson AJ, Grant I, Moffat LE, Heys SD \& Wahle KW (2004) Conjugated linoleic acids (CLAs) decrease prostate cancer cell proliferation: different molecular mechanisms for cis9, trans-11 and trans-10, cis-12 isomers. Carcinogenesis 25, $1185-1191$.

O’Shea M, Devery R, Lawless F, Murphy J \& Stanton C (2000) Milk fat conjugated linoleic acid (CLA) inhibits growth of human mammary MCF-7 cancer cells. Anticancer Res 20, 3591-3601.

Palombo JD, Ganguly A, Bistrian BR \& Menard MP (2002) The antiproliferative effects of biologically active isomers of conjugated linoleic acid on human colorectal and prostatic cancer cells. Cancer Lett 177, 163-172.

Pariza MW, Park Y \& Cook ME (2000) Mechanisms of action of conjugated linoleic acid: evidence and speculation. Proc Soc Exp Bio Med 223, 8-13.

Pariza MW, Park Y \& Cook ME (2001) The biologically active isomers of conjugated linoleic acid. Prog Lipid Res 40, 283-298.

SAS Institute Inc. (1989) SAS/STAT User's Guide, version 6, 4th ed. Cary, NC: SAS Institute Inc.

Sébédio JL, Prevost J \& Grandgirard A (1987) Heat treatment of vegetable oils. Isolation of cyclic fatty acid monomers from heated sunflower and linseed oils. J Am Oil Chem Soc 64, 1026-1032.

Shultz TD, Chew B, Seaman WR \& Luedecke LO (1992) Inhibitory effect of conjugated dienoic derivatives of linoleic acid and betacarotene on the in vitro growth of human cancer cells. Cancer Lett 63, 125-133. 